\title{
Factors Influencing Adoption of Mobile Banking by Jordanian Bank Customers: Extending UTAUT2 with Trust
}

\author{
Ali Abdallah Alalwan \\ Amman College of Banking and Financial Sciences, Al-Balqa' Applied University, Amman, \\ Jordan P.O: Amman 1705 Jordan Email: alwan.a.a.ali@gmail.com \\ Yogesh K. Dwivedi and Nripendra P. Rana \\ Emerging Markets Research Centre (EMaRC), School of Management, Swansea University, \\ Swansea, SA2 8PP, United Kingdom \\ Email: ykdwivedi@gmail.com nrananp@gmail.com
}

\begin{abstract}
Banks seem to be one of the most business that are really interested in such systems to provide their customers better services as well as to enhance their effectiveness and efficiency. However, the successful implementation of Mobile banking largely depends on the extent of how much customers are fully motivated to adopt it. In fact, over the Jordanian context, the adoption rate of mobile banking is very low and quite few studies that have examined the related issues of mobile banking. Thus, the purpose of this study is to investigate the factors influencing behavioural intention and adoption of Mobile banking by customers of Jordanian banks. The proposed model has assimilated factors from the extended Unified Theory of Acceptance and Use of Technology (UTAUT2) along with trust. Data was collected by conducting a field survey questionnaire completed by 343 participants. The results mainly showed that behavioural intention is significantly and positively influenced by performance expectancy, effort expectancy, hedonic motivation, price value and trust. This study also looking forward to providing the Jordanian banks with applicable guidelines for effectively implementing and designing Mobile banking. Furthermore, research limitations and future directions will be discussed further in the last section.
\end{abstract}

Keywords: Mobile banking, Adoption, Jordan. Customers, UTAUT2

\section{Introduction}

As one of the most innovative and novel technologies, Mobile banking represents a good example of a mobile technology breakthrough in the banking sector, enabling customers to independently produce financial transactions (i.e. balance enquiries, fund transfers, payment of bills) through mobile devices, smartphones, or Personal Digital Assistants (PDA) at the time and place that customers choose (Alalwan et al., 2016a, 2016c; Cruz et al., 2010; 
Laukkanen, 2007a, 2007b; Laukkanen and Cruz, 2009; Lee et al., 2014; Lin, 2011, 2013; Luarn and Lin, 2005; Püschel et al., 2010).

Increasingly, banks seem to be more motivated to integrate the Mobile banking channels in their logistical systems and a lot of financial and technical resources that have been devoted in this regard (Lin, 2013). Such of that more than $\$ 115$ billion has been invested by banks worldwide to implement the Mobile banking technology in their systems by the end of 2013 (Compete Pulse, 2013). This acceleration in Mobile banking could be initially attributed to a technological breakthrough in mobile and telecommunication technology. Indeed, this revolution provides solutions enabling banks to efficiently serve their customers with best quality and within large regions, particularly where there are restrictions in the term of Internet networks or establishing traditional branches (Cruz et al., 2010; Laukkanen and Cruz, 2009; Wessels and Drennan, 2010). Moreover, by increasing the number of mobile subscribers worldwide, the potential market of Mobile banking services is more likely to expand and attract more customers, thus serving the aspirations of both customers and banks in this respect as well (Alalwan et al., 2016c; Gu et al., 2009; Lee et al., 2014; Lin, 2013; Wessels and Drennan, 2010). For example, the number of Mobile banking users is expected to reach 1 billion by 2017 as reported by Compete Pulse (2013).

With regards to the implementation of Mobile banking channels in the Jordanian banking context, it is important initially to consider that Jordan has one of the fastest growing mobile and telecommunication technology sectors of the countries in the Middle East (The Gulf Today, 2012). For instance, there are four mobile service providers working within the Jordanian mobile market (The Jordan Times, 2013). This is also accompanied by the increasing penetration rate of mobile services. For instance, the number of Mobile phone subscribers in Jordan has exceeded 10 million by the end of 2014 (BuddeComm, 2014). Accordingly, as a competitive necessity as well as to improve customer satisfaction and loyalty, out of the 26 banks in Jordan, 15 banks have introduced Mobile banking services (Migdadi, 2012).

However, the adoption rates of the Mobile banking services do not reach the expected level especially in the developing countries and customer express less interest toward such services (Alalwan et al., 2016a; Hanafizadeh et al., 2014; Hossain and Dwivedi, 2014; Lin, 2011, 2013; Purwanegara et al., 2014; Püschel et al., 2010; Zhou, 2011, 2012; Weerakkody et al., 2013). For example, based on KPMG International's (2009, cited by Cruz et al., 2010) survey, which polled nearly 4,000 subscribers of mobile services in 19 countries around the 
world, the number of users of Mobile banking was $19 \%$ of the users of mobile phones. Likewise, Jordanian banking customers express less interest and motivation toward online banking channels in general and Mobile banking as more new banking technology in particular (Alalwan et al., 2015a; Alalwan et al., 2016b; Alalwan et al., 2014; Awwad and Ghadi, 2010; Khraim et al., 2011).

Accordingly, it could be argued that the biggest challenge for the success of this technology is in convincing the consumers to use it as a full alternative for traditional channels (Laukkanen et al., 2007). In fact, as Mobile banking is in the early stage of its implementation in Jordan, quite a few numbers of researchers (i.e. Alalwan et al., 2016b; Awwad and Ghadi, 2010; Khraim et al., 2011) have addressed the related issues of such technology. Even though these studies enriched the understanding the main predictors of the adoption of Mobile banking in Jordan, there are other relevant factors such as the roles of the external environment (e.g. facilitating conditions), service value (price value), and intrinsic motivation (hedonic motivation) call for further explanation in the Jordanian context. Thus, the gap relating to Mobile banking literature could be summarised in a necessity of proposing a parsimony conceptual model, which can accurately clarify the adoption of Mobile banking from the perspective of Jordanian customers. In addition, there is a need to apply sophisticated statistical approaches such as structural equation modelling (SEM) to empirically test the most important factors affecting intention and usage of Mobile banking in Jordan. Hence, in order to fill this gap, this study aims to empirically examine the most important factors that could shape the Jordanian customers' intention and adoption of Mobile banking.

\section{Literature Review}

Examining and explaining customer intentions and the adoption of Mobile banking have been recently the focus for scholars and practitioners worldwide, and this issue has seen a dramatic growth in the relevant literature of online banking channels ( $\mathrm{Gu}$ et al., 2009; Lin, 2011; Purwanegara et al., 2014; Püschel et al., 2010; Zhou, 2012). Indeed, by using different approaches and according to a variety of theoretical foundations, researchers progressively attempt to explain how customers formulate their perceptions, attitudes, intention and behaviour toward Mobile banking (Alalwan et al., 2016a; Lee et al., 2014; Hanafizadeh et al., 2014; Lin, 2011; Lin, 2013; Purwanegara et al., 2014). 
For instance, according to a qualitative study was conducted early by Lee et al. (2003), innovation characteristics - relative advantage, compatibility, trialability and complexity play a considerable role in forming customer attitudes to adopting Mobile banking. Likewise, Püschel et al. (2010) claimed that Brazilian customers' attitudes towards Mobile banking were significantly affected by relative advantage, followed by compatibility; ultimately enriching the customers' intention to adopt Mobile banking. In South Africa, Brown et al. (2003) found that banking customers are more enthused to adopt Mobile banking by relative advantage, trialability, and consumer banking needs. Similarly, ease of use, customer trust (integrity and competence), relative advantage, and compatibility were found by Lin (2011) to be key drivers of customers' attitudes towards Mobile banking, and ultimately facilitated the customers' willingness to adopt Mobile banking.

Recently, Purwanegara et al. (2014) assured the important role of perceived benefits and governmental regulations in forming customer attitudes towards Mobile banking in Indonesia. Other studies conducted by Hanafizadeh et al. (2014) in Iran and Wessels and Drennan (2010) in Australia found that customers seem to be more motivated to use Mobile banking if they recognised Mobile banking as being useful in their daily life, compatible with their habits and other technologies, and less expensive. In Singapore, Riquelme and Rios (2010) revealed that customer willingness to adopt Mobile banking was positively influenced by the role of perceived usefulness and social norms, and negatively predicted by increasing the level of perceived risk. Zhou (2012) empirically supported the considerable role of a bank's reputation, information quality, self-efficacy, service quality, and system quality in shaping the customers' initial trust in Mobile banking. Nevertheless, Cruz et al. (2010) recognised that the issues of lack of information, lack of observability, and unsuitable devices received less attention from non-users of Mobile banking.

The customers' apprehensions regarding safety issues and initial costs pertaining to setting up the Internet connections were seen by Yang (2009) as key hindrances to the adoption of Mobile banking. According to Yu (2012) and Hanafizadeh et al. (2014), customers are less likely to accept Mobile banking if they perceive a higher monetary cost in comparison with other traditional channels. Further, Jeong and Yoon (2013) found that financial cost was the least important factor when predicting a customer's intention to adopt Mobile banking. Perceived risk has been commonly observed as a negative factor hindering the customers' tendency to adopt Mobile banking (Brown et al., 2003; Hanafizadeh et al., 2014; Jeong and Yoon, 2013; Lee et al., 2003; Lee et al., 2007; Luo et al., 2010; Purwanegara et al., 2014). 
In conclusion, despite these studies providing a further understanding regarding the main factors predicting customer intention and usage of Mobile banking, there are still other important aspects that have to be explained.

Firstly, Mobile banking is considered as a novel and pioneer technology and therefore, as stated over the IS/IT literature (i.e. Brown and Venkatesh 2005; van der Heijden 2004; Venkatesh et al., 2012), intrinsic motivation could play a crucial role in motivating customer intention to adopt. However, the role of intrinsic motivation has still not been fully addressed in the relevant studies into Mobile banking.

Secondly, according to Venkatesh et al. (2012), in the customer context, price issues were found to be critical and received particular interest from customers when they were in the process of accepting or rejecting innovations. In addition, customers seem to be weighing up the utilities received and the financial cost of using a new technology (Dodds et al. 1991; Venkatesh et al., 2012). Yet, the vast majority of prior studies into Mobile banking have concentrated on the functional and non-monetary value (e.g. mobility, usefulness, performance expectancy) (e.g. Zhou, 2012), or focused on the associated financial cost as a barrier to using Mobile banking (e.g. Hanafizadeh et al., 2014) while the price or monetary value of using Mobile banking has not been covered well. Therefore, as an innovation technology comprising of different values as well as using it could carry a further cost to the customers; it is necessary to explain the role of monetary value on the customers' intention to use such technology. Moreover, it could be worth seeing how the functional and intrinsic utilities can enhance the price value of using Mobile banking; and ultimately, contribute to the role of price value on customer intention.

More importantly, researchers have formulated different models and theories from the IS/IT area such as: the Innovation Diffusion Theory (IDT) (Rogers, 2003) by Lin (2011) and Kim et al. (2009); the Technology Acceptance Model (TAM) (Davis et al., 1989) by Gu et al. (2009); the Theory of Planned Behaviour (TPB) (Ajzen, 1991) by Luarn and Lin (2005); the Decomposed Theory of Planned Behaviour (DTPB) by Püschel et al. (2010); the Unified Theory of Acceptance and Use of Technology (UTAUT) (Venkatesh et al., 2003) as by Zhou et al. (2010). However, upon further reflection, it became apparent that most of these theories and models were originally proposed in an organisational context (e.g. TAM and UTAUT) (Venkatesh et al., 2012). This leads to a concern regarding their applicability in customerfocused contexts (Venkatesh et al., 2012). Therefore, due to a variance between the customers and the organisational context in terms of which and how factors can form the 
individual's intention and behaviour towards technology, there is a need to select the theoretical framework that is appropriate for the customer (i.e. individual consumer) context (Venkatesh et al., 2012). This framework should also be able to cover the main aspects relating to the individual customers' intention and adoption of Mobile banking.

\section{Conceptual Model}

The extended Unified Theory of Acceptance and Use of Technology (UTAUT2) is specifically proposed to clarify the technology acceptance from the customer perspective. Therefore, in quest of selecting an appropriate model covering almost all constructs determining Jordanian consumer intention and adoption of Mobile banking, the UTAUT2 has been found as a theoretical foundation for proposing the conceptual model utilised in this study. As shown in Figure 1, the main constructs in the UTAUT2: performance expectancy (PE), effort expectancy (EE), social influence (SI), hedonic motivation (HM), and price value (PV) were proposed as direct determinants of customers' intention to adopt Mobile banking. In keeping with Venkatesh et al. (2012), two factors: behavioural intention (BI) and facilitating conditions (FC) both were identified as key predictors of adoption behaviour of Mobile banking. Instead of what has been proposed by Venkatesh et al. (2012), current research model does not consider the role of habit. This was based on the fact that in order to examine the role of habit, customers should have a rich experience in using such technology. A large number of respondents of current research are potential users who have not yet tried or used such system. Further, Mobile banking has been newly introduced by Jordanian banks (Alalwan et al., 2016b), which require a sufficient time by Jordanian customer to formulate a habitual behaviour toward such application. Therefore, it was difficult to examine the role of habit in the current study and the decision was made to exclude the role of habit.

According to prior literature of Mobile banking, trust (TR) has been highly approved as crucial factor determining customer's perception and intention to adopt such technology (Alalwan et al., 2015b; Hanafizadeh et al., 2014; Luo et al., 2010; Zhou, 2011; 2012). This interest could be attributed to the particular nature of electronic banking services that are characterized with the high uncertainty coupled with the nature of the financial service, which could be characterized as high risky product (Hanafizadeh et al., 2014; Luo et al., 2010; Zhou, 201). Therefore, as external factor, TR has been included as an extension to the UTAUT2 in the same conceptual model as highly recommended by Venkatesh et al. (2012) to broaden the theoretical horizon of UTAUT2. 


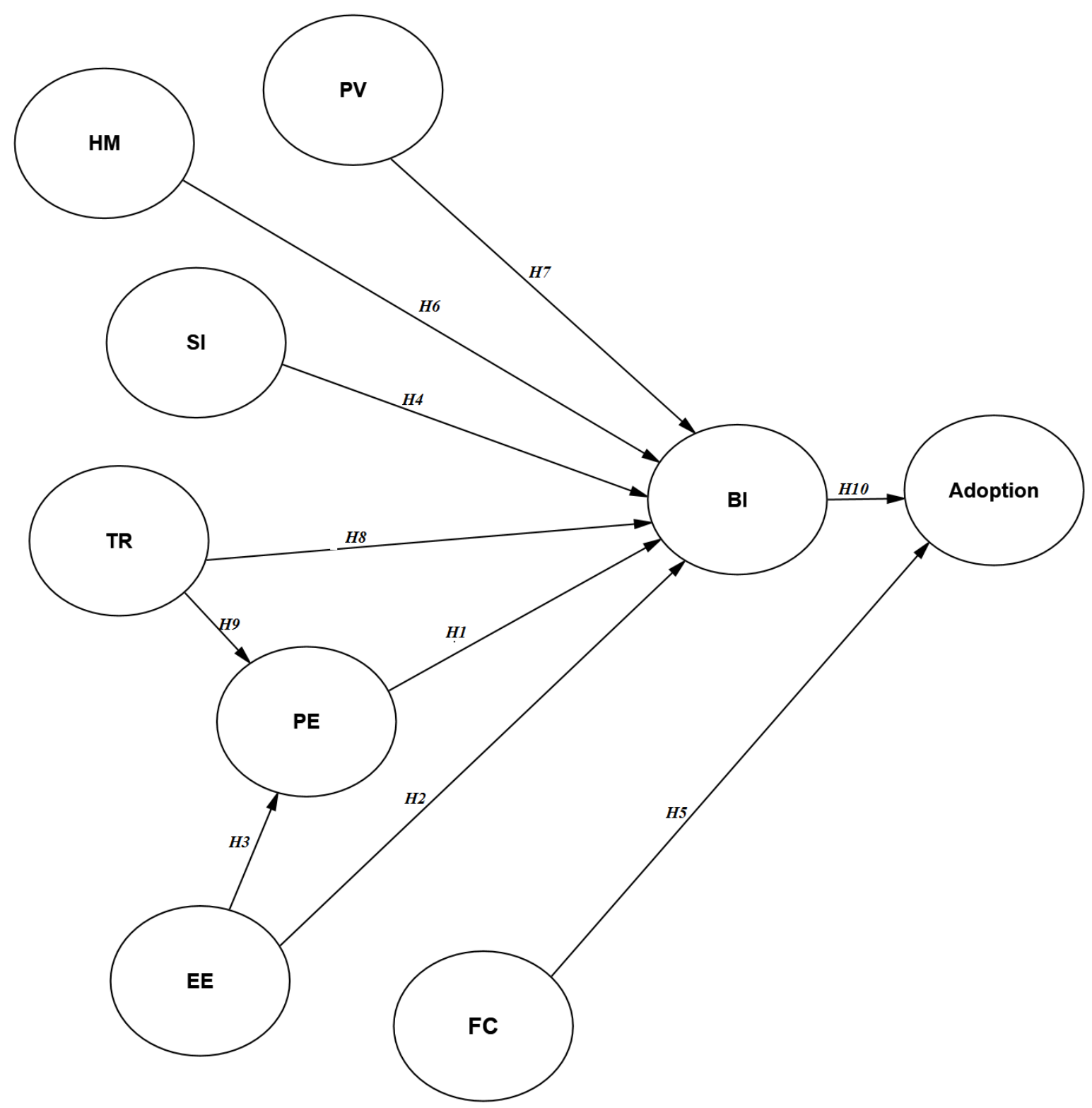

Figure 1: Proposed Conceptual Model (Adapted from Gefen et al., 2003; Venkatesh et al., 2012)

\subsection{Performance Expectancy}

$\mathrm{PE}$ is conceptualised "as the degree to which an individual believes that applying the technology will help him or her to attain gains in job performance" (Venkatesh et al., 2003, p. 447). Broadly speaking, customers seem to be more motivated to use and accept new technology if they perceive that this technology is more advantageous and useful in their daily life (Alalwan et al., 2016b; Davis et al., 1989; Venkatesh et al., 2003). According to prior Literature, Mobile banking has also been widely attributed as a more convenient channel that allows customers to access a wide range of services with flexibility in time and place (Alalwan et al., 2016a; Gu et al., 2009; Luarn and Lin, 2005; Riquelme and Rios, 2010). Particularly, in their study to investigate the acceptance of Mobile banking, Zhou et al. 
(2010) concluded that the clients' intention to use Mobile banking is significantly predicted by the performance expectancy.

Therefore, this study articulates the following hypothesis:

H1: Performance expectancy will positively influence Jordanian customers' intention to adopt Mobile banking.

\subsection{Effort Expectancy}

Venkatesh et al. (2003, p.450) defined EE as "the extent of ease connected with the use of a system. In line with Davis et al. (1989), the individual's intention to accept a new system is not only predicted by how much the system is positively valued but also by how much using this system is not difficult and requires free efforts. Therefore, due to the particular nature of Mobile banking, which require a certain level of knowledge and skill, effort expectancy could play a crucial role in determining the customers' intention to use such technology (Alalwan et al., 2016a). Several authors over the relevant area of interest have validated the impact of effort expectancy on the customer's intention to use online banking channels (Alalwan et al., 2016b; Riffai et al., 2012; Martins et al., 2014). The captured factors of EE (i.e. perceived ease of use) have been verified by different Mobile banking studies to have a crucial role in predicting customers intention to use Mobile banking ( $\mathrm{Gu}$ et al., 2009; Riquelme and Rios, 2010; Luarn and Lin, 2005). Thus, this study assumes the following hypotheses.

H2: Effort expectancy will positively influence Jordanian customers' intention to adopt Mobile banking.

\section{H3: Effort expectancy will positively influence performance expectancy of} Mobile banking.

\subsection{Social influence}

According to the UTAUT model, social influence is characterised as "the extent to which an individual perceives that important others believe he or she should apply the new system" (Venkatesh et al., 2003, p. 450). As for the Mobile banking, social influence could be conceptualised as the influence of the surrounding social environment on a customers' intention to adopt Mobile banking; for example, reference groups, family, opinionated leaders, friends and colleagues (e.g. Zhou et al., 2010). In different words, the information and encouragements provided by people surrounding customers could play a dynamic role in 
contributing to the customers' awareness as well as the intention toward technology (Alalwan et al., 2016b; Alalwan et al., 2015a). The selection of social influence as a key determinant of the behavioural intention is built on prior literature which supports the impacting role of social influence on customers' propensity to use online banking channels (Alalwan et al., 2016b; Martins et al., 2014; Riquelme and Rios, 2010; Yu, 2012; Zhou et al., 2010). Consequently, this study postulates the next hypothesis:

\section{H4: Social influence will positively influence Jordanian customers' intention to adopt Mobile banking.}

\subsection{Facilitating Conditions}

Facilitating conditions are defined as "the degree to which an individual believes that an organizational and technical infrastructure exists to support the use of the system" (Venkatesh et al., 2003, p. 453). Indeed, using online banking channels usually require a particular kind of skill, resources and technical infrastructure (Alalwan et al., 2016b; Alalwan et al., 2015; Zhou et al., 2010). Therefore, customers could be more motivated to use Mobile banking if they have an certain level of support service and resource as well as perceive Mobile banking as compatible with other technologies already used by them. Theoretically, the impacting role of facilitating conditions on the usage behaviour toward using Mobile banking has been supported by different online banking studies (Alalwan et al., 2015b; Alalwan et al., 2016b; Alalwan et al., 2014; Yu, 2012; Zhou et al., 2010). Accordingly, this study proposes the following hypothesis:

H5: Facilitating conditions will positively influence Jordanian customers' adopt Mobile banking.

\subsection{Hedonic Motivation}

Basically, Venkatesh et al. (2012) proposed a direct link between hedonic motivation and customer intention to use technology. Intrinsic utilities (i.e. joy, fun, playfulness, entraining, and enjoyment) have been included Venkatesh et al. (2012) under the concept of hedonic motivation alongside extrinsic utilities (i.e. efficiency, usefulness, performance expectancy) in the same model (Venkatesh et al., 2012). Indeed, over the IS literature, it has been highly argued that intrinsic utilities could have a curial role in accelerating individuals intention to adopt the emerging systems (i.e. Van der Heijden, 2004). This role seems to be more powerful in the case of hedonic systems that characterize high degree creativity and 
uniqueness as in the case of Mobile banking in Jordan (Alalwan et al., 2014; Brown and Venkatesh, 2005; Püschel et al., 2010; Van der Heijden, 2004). For instance, Alalwan et al., (2016b) provided strong evidences supporting the role of hedonic motivation in shaping customers' decision to adopt Telebanking by Jordanian customers. Accordingly, this study proposes the following hypothesis:

\section{H6: Hedonic motivation will positively influence Jordanian customers' adopt Mobile banking.}

\subsection{Price Value}

In comparison with organisational sitting, using technology over the customers context could carry customers further financial cost. Therefore, customers could cognitively compere the utilities comprised in using new systems with the financial cost that should be paid for using such systems (Venkatesh et al., 2012). To put differently, with the higher positive level of price value, customers will be more enthused to adopt new technology. This, in turn, requires customers that using technology should be perceived as more advantageous and useful than the monetary cost paid (Venkatesh et al., 2012). More importantly, the facilities and resources required (e.g. 4G services, smart phones, Wi-Fi) to run Mobile banking could attach customers further financial cost, thus, enhancing the important role of price value among the conceptual model (Alalwan et al., 2016b; Riquelme and Rios, 2010; Gerrard et al., 2006; Sathye, 1999). In the line with this assumption, according to Yu (2012) and Luarn and Lin (2005), the customers' predisposition to adopt Mobile banking is strongly determined by budget constraints. Yang (2009) also argued that while the cost of mobile services was found to be the most negative determinant to the adoption of Mobile banking, lower costs of financial transactions applied by Mobile banking were found to be one of the positive influences on the adoption of Mobile banking.

The relationship between service value and price value has been argued and addressed over the relevant studies of online banking channels. For instance, Ho and Ko (2008) empirically proved the role of perceived value in contributing the customers' intention to use Internet banking. Likewise, monetary value is recognised as a critical influence on the adoption of Internet banking, particularly for potential adopters who are more likely to accept this channel over a year (Lee et al., 2005). Consequently, this study proposes that:

\section{H7: Price value will positively influence Jordanian customers' intention to} Mobile banking. 


\subsection{Trust}

In the line with Gefen's et al., (2003) definition of trust, customer trust in Mobile banking can be operationalised as the accumulation of customer beliefs of integrity, benevolence and ability that could enhance customer willingness to depend on Mobile banking to attain the financial transactions. Trust has been widely examined and proven to be a crucial factor predicting customer's perception and intention toward Mobile banking (Hanafizadeh et al., 2014; Luo et al., 2010; Zhou, 2012). For instance, trust was empirically supported by Luo et al. (2010) to have significant influence not only on the customer's intention but also on performance expectancy. In his study to examine the factors predicting customers' initial trust in Mobile banking, Zhou (2011) also confirmed trust as key factor determining the likelihood of customers using Mobile banking. The role of trust and perceived credibility have been sustained by Hanafizadeh et al. (2014) as key drivers for the adoption of Mobile banking by Iranian bank customers as well. In the current study and as proposed by Gefen et al. (2003), trust is supposed to have a direct effect on the customers' intention to adopt Mobile banking or it could indirectly influence BI via facilitating the role of performance expectancy.

Therefore, this study proposes the following hypotheses:

H8: Trust will positively influence Jordanian customers' intention to adopt Mobile banking.

H9: Trust will positively influence the performance expectancy associated with using Mobile banking.

\subsection{Behavioural Intention}

Over the prior literature of IS/IT, behavioural intention has been largely and repetitively reported to have a strong role in shaping the actual usage and adoption of new systems (Ajzen, 1991; Venkatesh et al., 2003, 2012). Accordingly, the current study supposes that the actual adoption of Mobile banking could be largely predicted by the customers' willingness to adopt such system. This relationship has also been largely proven by many online banking studies such as in the studies of Jaruwachirathanakul and Fink (2005), Martins et al. (2014), and many others.

Consequently, this study proposes that:

H10: Behavioural intention will positively influence Jordanian customers' adoption of Mobile banking. 


\section{Methodology}

So as to obtain the empirical data needed to validate the conceptual model and examine the research hypotheses, 500 self-administered questionnaires were allocated to derive responses from Jordanian banking customers regarding their perception of the aspects related to behavioural intention and adoption of Mobile banking. As shown in Table 1, 36 scale items have been used in the current study to measure the fundamental constructs in the conceptual model. Particularly, the main constructs of UTAUT2 (PE, EE, SI, FC, HM, PV, and BI) were measured by same items used by Venkatesh et al. (2012) in validating their new model (UTAUT2). Customers' trust in Mobile banking was measured by six items taken form Gefen et al. (2003). Conceptually, Gefen $(2000 ; 2002)$ and Gefen et al. (2003, p.161) have defined trust as "individual willingness to depend based on the beliefs in ability, benevolence, and integrity”. In the line with Gefen $(2000 ; 2002)$ and Gefen et al. (2003), customer trust in the current study was operationalized as accumulation of trust beliefs: integrity, benevolence, and ability that relate with the bank and Mobile-banking channel. Therefore, items of trust selected in a manner to cover the main aspects of customers' perception of trust: ability, benevolence, and integrity as documented by Gefen et al. (2003). To measure the respondents' responses on items of UTAUT2 constructs and trust, the seven-point Likert scale with anchors ranging from strongly agree to strongly disagree was adopted in this study. As for the adoption of Mobile banking, this study adopted five of the most frequently used Mobile banking services to measure the adoption behaviour toward Mobile banking services (see Table 1). Actually, such services have been adopted according to recommendations introduced by online banking experts in the largest banks in Jordan such as Bank of Jordan, Housing Bank, Arab Bank, Kuwait Bank, Jordan Islamic Bank, and Cairo Amman Bank. To measure the extent of how much respondents use these services, this study used the seven-point time scale with anchors ranging as follows: never, once a year, several times a year, once a month, several times a month, several times a week, several times a day (Venkatesh et al., 2012). Finally, six close-ended questions were devoted for demographic variables: age, gender, income, education level, Internet experience, and computer experience. Bearing in the mind the main language of participates (Jordanian banking customers) in the current study is Arabic as well as to avoid the impact of cultural and language differences, back translation method was adopted to transform the targeted questionnaire to Arabic language (Brislin, 1976). 


\section{Results}

\subsection{Respondents' Profile and Characteristics}

Three hundred forty-three valid questionnaires of Mobile banking were completed by Jordanian banking customers. $65.6 \%$ of the respondents were male compared to $34.4 \%$ of the total respondents who were female. Relating to respondents age, it was noticed that the age group of 25-40 captured the largest part of the total valid sample (65\%). With reference to the monthly income level, as seen in Table 5.14, the vast majority of respondents $(32.4 \%)$ had a monthly income level ranging from 400-600 Jordanian Dinar (JOD) followed by those (21\%) who had a monthly income ranging from 601-800 JOD. The descriptive statistics also show that the most prominent educational level of respondents $(72.3 \%)$ was the Bachelor Degree. In relation to computer experience, it was noticed that the great mass of respondents $(92.8 \%)$ were observed to have a sufficient level of computer experience and Internet (more than 3 years).

\subsection{Normality}

A skewness-kurtosis approach was adopted to test univariate normality for each variable (Byrne, 2010; Hair et al., 2010; Kline, 2005). Using AMOS 21.0, the statistical values of skewness and kurtosis were tested and found they were within their respective levels. As reported in Table 1, all the values given support the normality of univariate distribution due to all values of skewness were recognised to be below their cut-off point of ' 3 ' as well as all values of kurtosis were found to be not more than ' 8 ' (Kline, 2005; West et al., 1995). 
Table 1: Assessment of Normality

\begin{tabular}{|c|c|c|c|}
\hline Constructs & Items & Skewness & Kurtosis \\
\hline \multirow{4}{*}{ Performance Expectancy } & PE1 & -1.118 & 1.149 \\
\hline & PE2 & -0.751 & 0.231 \\
\hline & PE3 & -1.159 & 1.177 \\
\hline & PE4 & -0.763 & 0.394 \\
\hline \multirow{4}{*}{ Effort Expectancy } & EE1 & -1.252 & 1.752 \\
\hline & EE2 & -1.151 & 1.107 \\
\hline & EE3 & -1.069 & 1.103 \\
\hline & EE4 & -0.947 & 0.643 \\
\hline \multirow{3}{*}{ Social Influences } & SI1 & -0.557 & -0.344 \\
\hline & $\mathrm{SI} 2$ & -0.535 & -0.375 \\
\hline & SI3 & -0.591 & -0.236 \\
\hline \multirow{4}{*}{ Facilitating Conditions } & FC1 & -0.671 & 0.012 \\
\hline & $\mathrm{FC} 2$ & -0.721 & -0.056 \\
\hline & FC3 & -0.692 & -0.008 \\
\hline & FC4 & -0.779 & 0.239 \\
\hline \multirow{3}{*}{ Hedonic Motivation } & HM1 & -0.864 & 0.549 \\
\hline & HM2 & -0.648 & 0.031 \\
\hline & HM3 & -0.589 & -0.227 \\
\hline \multirow{3}{*}{ Price Value } & PV1 & -0.584 & 0.213 \\
\hline & PV2 & -0.502 & -0.173 \\
\hline & PV3 & -0.661 & 0.041 \\
\hline \multirow{6}{*}{ Trust } & TR1 & 0.639 & 0.310 \\
\hline & TR2 & 0.595 & -0.018 \\
\hline & TR3 & 0.657 & 0.178 \\
\hline & TR4 & 0.507 & -0.013 \\
\hline & TR5 & 0.181 & -0.915 \\
\hline & TR6 & 0.547 & -0.161 \\
\hline \multirow{4}{*}{ Behavioural Intention } & BI1 & -0.956 & 0.786 \\
\hline & $\mathrm{BI} 2$ & -0.801 & 0.267 \\
\hline & $\mathrm{BI} 3$ & -0.748 & 0.065 \\
\hline & BI4 & -0.966 & 0.852 \\
\hline \multirow{6}{*}{ Use Behaviour } & Service1 & -0.301 & -1.196 \\
\hline & Service2 & 0.796 & -0.221 \\
\hline & Service3 & 0.802 & -0.716 \\
\hline & Service4 & 0.155 & -1.257 \\
\hline & Service5 & 1.670 & 1.843 \\
\hline & Service6 & 1.214 & 0.078 \\
\hline
\end{tabular}

\subsection{Structural Equation Modelling Analysis}

The collected data has been subjected for further analyses in the structural equation modelling (SEM). Indeed, the two-stage SEM approach was employed to begin with by evaluating the measurement model and then estimating the structural model. All the UTAUT2 constructs and trust were subjected to the measurement model analyses followed by the structural model analyses. Noteworthy, an examination of structural model was conducted including the UTAUT2 constructs without trust. Such process was important to be conducted to see how the predictive power of the model could be different with and without trust. 


\subsubsection{Measurement Model: Confirmatory Factor Analysis}

Model fitness (unidimensionality) was tested initially in the CFA followed by evaluating the constructs reliability and validity.

\subsubsection{Model fitness}

The main fit indices including CMIN/DF, AGFI, GFI, NFI, CFI, and RMSEA have all been tested to evaluate the model fitness. As seen in Table 2, the yielded fitness indices regarding the initial measurement model of Mobile banking were realised as follow: CMIN/DF was 2.066, GFI=0.85, AGFI=0.81, NFI=0.89, CFI=0.945 and RMSEA=0.057. Owing to the fact that some of these indices were not able to reach their threshold value (i.e. GFI, NFI) (Hair et al., 2010), further purifications and reassessments were done so as to enhance the model fitness (Anderson and Gerbing, 1988; Bagozzi and Yi, 1988; Byrne, 2010;). Fundamentally, a refinement process followed a number of criteria to enhance the model's fitness including inspection of standardised regression weights (factor loading), modification indices, and standardised covariance matrix (Byrne, 2010; Hair et al., 2006; Holmes-Smith et al., 2006).

By inspecting of standardised regression weights (factor loading), one items (Service5) from adoption behaviour and one item (TR3) from trust were observed to be under their cut-off value (higher than 0.50) (Hair et al., 2010; Byrne, 2010). Hence, the decision was to remove these two items. Besides, according to the modification indices, it was observed that one item of behavioural intention (BI4), one item of performance expectancy (PE1), one item of facilitating conditions (FC4), one item of hedonic motivation (HM3), one item of social influence (SI2), and one item of price value (PV1) had a higher unacceptable value. Thus, a decision was taken to remove these six items. By looking at standardised residual covariance, one item of effort expectancy (EE2) and one items of trust (TR1) had residual values of 3.171 and 3.412 respectively and were higher than their respective level of \pm 2.58 (Hair et al., 1995). Therefore, these two items were subjected as removable items.

By doing so, the CFA was tested again without these redundant items, and as expected the model fitness improved considerably. Even though the value of chi-square (CMIN=484.182, $\mathrm{DF}=263, \mathrm{P}=0.000)$ is still significant, the rest of the fit indices of the modified measurement model, as seen in Table 2, were found to be within their recommended values: CMIN/DF was $1.841, \mathrm{GFI}=0.903, \mathrm{AGFI}=0.87, \mathrm{NFI}=0.932, \mathrm{CFI}=0.968$ and $\mathrm{RMSEA}=0.050$ (Anderson and Gerbing, 1988; Hair et al., 2010). Accordingly, demonstrating that the modified measurement 
model had a high adequate goodness of fit to the data, there is no longer a need for respecifying and improving the model (Byrne 2010; Hair et al., 2010).

Table 2: Results of Measurement Model

\begin{tabular}{|l|c|c|c|}
\hline Fit indices & Cut-off point & Initial measurement model & Modified measurement model \\
\hline CMIN/DF & $\leq 3.000$ & 2.066 & 1.841 \\
\hline GFI & $\geq 0.90$ & 0.85 & 0.903 \\
\hline AGFI & $\geq 0.80$ & 0.81 & 0.87 \\
\hline NFI & $\geq 0.90$ & 0.89 & 0.932 \\
\hline CFI & $\geq 0.90$ & 0.945 & 0.968 \\
\hline RMSEA & $\leq 0.08$ & 0.057 & 0.050 \\
\hline
\end{tabular}

\subsubsection{Construct Reliability}

As shown in Table 3, all constructs were tested to ensure an adequate level of scales reliability using Cronbach's alpha $(\alpha)$, composite reliability (CR), and average variance extracted (AVE). Statistical findings in this regards indicted that all latent constructs have Cronbach's alpha $(\alpha)$ value above the cut-off point of 0.70 ranging between 0.77 for social influence and 0.93 for behavioural intention (Nunnally, 1978). By the same token, CR for all latent constructs existed within their respective level of 0.70 as reported by Hair et al. (2010). Table 3 indicates that while the highest value of CR (0.92) was noticed for both facilitating conditions and behavioural intention, the minimum value was exhibited by social influence (0.78). Moreover, as seen in Table 3, the AVE value of the latent constructs ranged from 0.57 (social influence) to 0.80 (behavioural intention) which all are above the cut-off value of .50 as recommended by Hair et al. (2010).

Table 3: Constructs Reliability

\begin{tabular}{|l|c|c|c|}
\hline Latent Construct & $\begin{array}{c}\text { Cronbach's alpha } \\
(\boldsymbol{\alpha})\end{array}$ & $\begin{array}{c}\text { Composite Reliability (CR) } \\
\text { Average Variance } \\
\text { Extracted (AVE) }\end{array}$ \\
\hline PE & 0.90 & 0.89 & 0.69 \\
\hline EE & 0.87 & 0.87 & 0.69 \\
\hline SI & 0.77 & 0.78 & 0.57 \\
\hline HM & 0.92 & 0.91 & 0.79 \\
\hline PV & 0.84 & 0.85 & 0.73 \\
\hline TR & 0.88 & 0.88 & 0.79 \\
\hline BI & 0.89 & 0.88 & 0.65 \\
\hline UB & 0.93 & 0.92 & 0.80 \\
\hline
\end{tabular}

\subsubsection{Construct Validity}

Both convergent and discriminant validities were inspected to measure the construct validity. Relating to the convergent validity, the statistical findings noted that all un-removable items 
had a significant standardised regression weight with their latent constructs. In addition, all undeleted items had a factor loading as low as 0.54 which surpasses their cut-off point of 0.50; they were also found to be statistically significant with a $p$ value less than .0001 (Anderson and Gerbing, 1988; Hair et al., 2010). By investigating the correlation estimates among the latent constructs, the highest value of inter-correlation estimates was less than 0.72 which is below its maximum level of 0.85 (Kline, 2005). Furthermore, as seen in Table 4, all latent constructs had the squared root of AVE higher than their inter-correlation estimates with other corresponding constructs.

Table 4: Discriminant Validity

\begin{tabular}{|l|l|l|l|l|l|l|l|l|l|}
\hline LV & PE & EE & SI & FC & HM & PV & TR & BI & AD \\
\hline PE & $\mathbf{0 . 8 3}$ & & & & & & & & \\
\hline EE & 0.69 & $\mathbf{0 . 8 3}$ & & & & & & & \\
\hline SI & 0.56 & 0.63 & $\mathbf{0 . 7 5}$ & & & & & & \\
\hline FC & 0.44 & 0.57 & 0.41 & $\mathbf{0 . 8 9}$ & & & & & \\
\hline HM & 0.64 & 0.70 & 0.70 & 0.55 & $\mathbf{0 . 8 5}$ & & & & \\
\hline PV & 0.58 & 0.68 & 0.69 & 0.49 & 0.70 & $\mathbf{0 . 8 9}$ & & & \\
\hline TR & 0.54 & 0.54 & 0.65 & 0.43 & 0.65 & 0.65 & $\mathbf{0 . 8 0}$ & & \\
\hline BI & 0.67 & 0.68 & 0.61 & 0.50 & 0.72 & 0.70 & 0.70 & 0.89 & \\
\hline AD & 0.45 & 0.36 & 0.33 & 0.50 & 0.37 & 0.41 & 0.43 & 0.58 & 0.77 \\
\hline
\end{tabular}

\subsubsection{Common Method Bias}

To make sure that the dataset is free from common method bias, an inspection of Harman's single-factor with nine constructs (PE, EE, SI, FC, HM, PV, TR, BI and adoption) and 26 scale items was conducted (Harman, 1976; Podsakoff et al., 2003). The statistical results in this respect indicated that no single factor was able to emerge as well as the first factor was able to which accounted for $45.78 \%$ of variance which is less than the cut-off value of $50 \%$ as suggested by Podsakoff et al. (2003). Thus, the data set of Mobile banking does not have any concerns regarding the common method bias.

\subsubsection{Structural Model}

The yielded of fit indices of the structural model imply that the structural model had sufficient goodness of fit to observed data. Indeed, despite the fact that the chi-square was significant $\left(\chi^{2}=749.279, \mathrm{DF}=278, \mathrm{P}=0.000\right)$, the other fit indices were found to be within their threshold 
value as follows: $\mathrm{CMIN} / \mathrm{DF}=2.695, \mathrm{GFI}=0.901, \mathrm{AGFI}=0.837, \mathrm{NFI}=0.913, \mathrm{CFI}=0.952$ and RMSEA $=0.065$.

Pertaining to the path coefficient analyses, most of the causal paths proposed over the conceptual model were supported to be significant. Accurately, behavioural intention was found to be significantly predicted by UTAUT2 factors: performance expectancy $(\gamma=0.19$, $\mathrm{p}<0.001)$, effort expectancy $(\gamma=0.18, \mathrm{p}<0.016)$, hedonic motivation $(\gamma=0.20, \mathrm{p}<0.000)$ and price value $(\gamma=0.15, \mathrm{p}<0.041)$. Yet, social influence were not approved to have a significant path with behavioural intention $(\gamma=0.026, p<0.606)$. As for the main predictors of performance expectancy, both trust $(\gamma=0.24, p<0.000)$ and effort expectancy $(\gamma=0.56$, $\mathrm{p}<0.000)$ were proven to have a significant influence on performance expectancy. Finally, adoption of Mobile banking was also found to be significantly predicted by both behavioural intention $\gamma=0.467, p<0.001)$ and facilitating conditions $(\gamma=0.153, p<0.021)$. Accordingly, the research hypothesises: $\mathrm{H} 1, \mathrm{H} 2, \mathrm{H} 3, \mathrm{H} 5, \mathrm{H} 6, \mathrm{H} 7, \mathrm{H} 8, \mathrm{H} 9$ and $\mathrm{H} 10$ all were confirmed while only one hypothesis: $\mathrm{H} 4$ was rejected. The $R^{2}$ values extracted in the endogenous factors were found as follows: $65 \%$ for behavioural intention; $49 \%$ for performance expectancy; and $31 \%$ for adoption behaviour.

It is also worth mentioning that an examination of structural model was conducted without trust. As expected, the main constructs of the UTAUT2 (without trust) were able to predict about $59 \%$ of variance in behavioural intention. However, $R^{2}$ value accounted for behavioural intention was enhanced by the inclusion of trust along with the UTAUT2 constructs in the same structural model to reach $65 \%$. Accordingly, it could be concluded that the structural model seems to have more power in predicting the behavioural intention once trust is comprised together with the UTAUT2 constructs.

\section{Discussion}

According to the statistical results presented above, it seems obviously that the model being examined in the current study has been able to reach an accepted level in the terms of predictive power in all endogenous factors: behavioural intention (65\%), adoption behaviour $32 \%)$ and performance expectancy (49\%). This is also in addition to the fact all criteria related to measurement model: model fitness, construct reliability and validity were successfully achieved. By including trust along with UTAUT2 factor the $R^{2}$ value extracted in BI increase to reach $65 \%$, which in turn, supports comprising trust as external factor among the conceptual model. 
Such value of $R^{2}$ accounted in behavioural intention was also observed within a highly acceptable level, which exceeded all the recommended values in this regard, such as: $40 \%$ (Straub et al., 2004) and 30\% (Holmes-Smith et al., 2006; Kline, 2011). Moreover, this value of variance is fairly close to those accounted for by other studies formulating UTAUT. For instance, study of adoption Mobile banking carried out by Luo et al. (2010) accounted 60\% of variance in behavioural intention to use Mobile banking.

In relation to path coefficient analyses, trust was found to be the most significant factor predicting the customers' intention to adopt Mobile banking with a coefficient value of 0.26 . As well as, trust was able to have a significant path with performance expectancy with regression weight of 0.24 . This, in turn, implies the important role of trust not only in motivating the customer to use Mobile banking but also in shaping their perception toward such technology as more productive and novel technology. This could be return to the sensitive nature of financial transactions that are conducted by electronic channels (Eriksson et al., 2005; Riffai et al., 2012). Such results are in the line with what has been approved by prior IS and Mobile banking studies regarding the role of trust (Gefen et al., 2003; Hanafizadeh et al., 2014; Luo et al., 2010; Riffai et al., 2012; Zhou, 2012).

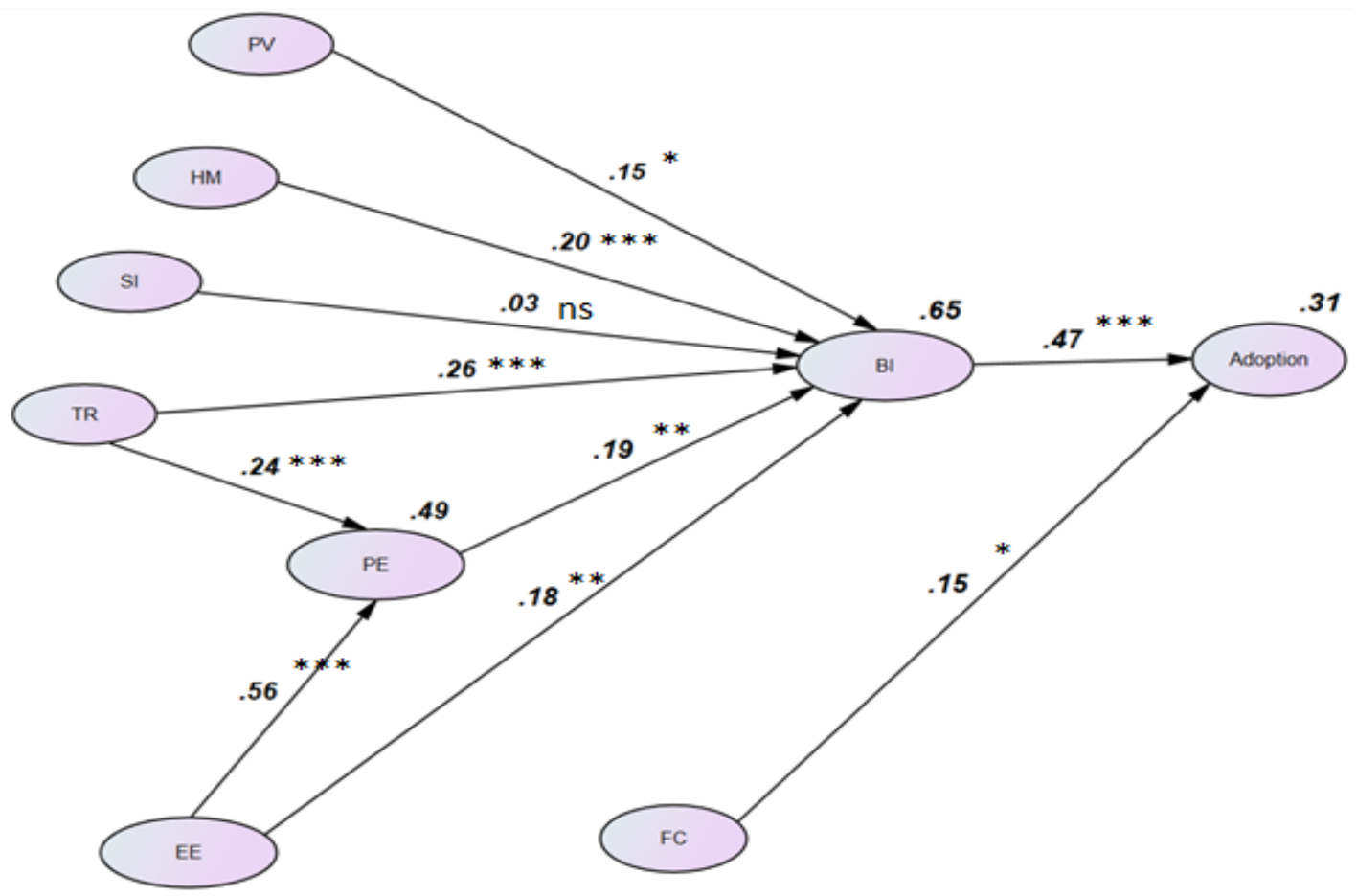

Figure 2: Validated Research Model 
Statistical results also provide strong proofs confirming the causal path between behavioural intention and performance expectancy with weight of 0.19 . This clearly implies that aspects related to the functional utilities (performance expectancy) are the focus of attention for the Jordanian consumers in formulating their intention to adopt Mobile banking. Theoretically, the vast majority of studies that have applied UTAUT as a theoretical foundation in their conceptual models have confirmed performance expectancy as a significant factor influencing behavioural intention (Alalwan et al., 2014; Luo et al., 2010; Martins et al., 2014; Riffai et al., 2012; Yu, 2012; Zhou et al., 2010).

The empirical results have supported the significant relationship between effort expectancy and behavioural intention to adopt Mobile banking with regression weight of 0.18 . This means that Jordanian customers seem to be concerned about the extent of simplicity or difficulty in using Mobile banking. Such relationship could be reasoned to the fact that the particular nature of Mobile banking requires customers to have a certain level of knowledge and skill, let alone, using these channels requires customers to perform all tasks alone without any assistance (Gu et al., 2009; Riquelme and Rios, 2010; Luarn and Lin, 2005).

Along with its direct influence on the behavioural intention, effort expectancy was approved to have a significant impact on performance expectancy. In other words, if the customers perceive that using technology needs less effort and is not difficult, they will perceive to use technology more advantageously and be useful in their life (Davis et al., 1989). Over the prior IS/IT literature, it has been largely argued that individuals' perception of the system usefulness is strongly influenced by the extent of how much such system is ease to use and does not require too much efforts (Davis et al., 1989; Eriksson et al., 2005). By the same token, several studies in the area of Mobile banking that reported a strong relationship between system ease of use and the usefulness of this systems (i.e. Luarn and Lin, 2005; Gu et al., 2009; Riquelme and Rios, 2010).

As for the role of social influence, the results have been noticed in a different manner for what has been proposed in the conceptual model of the current study. Indeed, social influence were not able to account for any statistical variance in the behavioural intention to adopt Mobile banking which means that Jordanian banking customers seem to be less interested to the recommendations and attitudes of their references groups (i.e. family, friends, colleagues) in formulating their intention to adopt technology. In fact, the results exhibited in this study regarding the social influence were found to be different in comparison with other studies that have applied UTAUT as a guiding model in their studies such as Yu (2012) and Zhou et al. 
(2010); they all supported the role of social influence on the behavioural intention. However, there are other studies in the relevant area that have disapproved the impact of social influence. For instance, a study employed UTAUT as a ground theory to predict the customers' intention to adopt online banking by Riffai et al. (2012) who found that social influence were the least non-significant factors predicting behavioural intention with a coefficient value of 0.10 . Such other examples pertaining to online banking channels found that social influence or similar factors (e.g. subjective norm, image, social desirability, and reference group) do not have a significant impact on the customers' intention to use these channels (Gerrard and Cunningham, 2003).

Statistical results empirically approved the considerable influence of facilitating conditions on adoption of Mobile banking $(\gamma=0.153, \mathrm{p}<0.021)$. This demonstrates that respondents pay a particular interest in the existence of facilities, resources, and skills that are required to use Mobile banking successfully and effectively. Indeed, the nature of the facilities that are required in the case of Mobile banking (i.e. smart phones, $4 \mathrm{G}$ services, Internet access, Wi-Fi, secured applications) are fundamental aspects to have a smooth and easy access to the financial services. Results of facilitating conditions are parallel with other results witnessed in the prior studies that have examined facilitating conditions or their captured factors (i.e. Alalwan et al., 2016b; Yu, 2012; Zhou et al., 2010).

As expected, hedonic motivation was empirically evidenced to be crucial factor influencing Jordanian customers 'intention to adopt Mobile banking $(\gamma=0.20, p<0.000)$. This strong association echoes that the likelihood of adopting Mobile banking could reach the highest level among banking clients who perceive further joy, entertaining, pleasure and enjoyment in using such novel channels. Indeed, intrinsic motivation enjoys a particular interest in the customers' context and its impact becomes more effective in the case of hedonic technology that comprises of novelty seeking and uniqueness (Brown and Venkatesh 2005; van der Heijden, 2004). Jordan is considered as one of the fastest growing countries in the Middle East in terms of mobile and telecommunication technology; using these channels (e.g. Internet banking, Mobile banking) represents an added value in the terms of novelty and modernism for the people there. This plausibly illustrates the active role of hedonic motivation in shaping the Jordanian customers' intention to use Mobile banking. Existing literature related to the information system area (Brown and Venkatesh, 2005; van der Heijden, 2004; Venkatesh, 1999) has largely supported the crucial role of intrinsic motivation in predicting the behavioural intention. 
As proposed in the conceptual model, statistical results affirmed a significant path between price value and customers 'intention to adopt Mobile banking with weight of 0.15 . Accordingly, it could be concluded that price value issues receive a particular interest from banking customers in Jordan to form their decision to adopt or reject Mobile banking. In different words, by increasing the level of the benefits and utilities perceived in using Mobile banking relative to the financial cost paid to use such systems, customer are more likely to be motivated to adopt Mobile banking. This is in line with Venkatesh et al.'s (2012) thought ensuring that the financial issues usually draw considerable attention to the customer context rather than the organisational context where the cost is comprised in terms of time and effort.

Besides, given the previous results regarding hedonic motivation and performance expectancy, it seems that Jordanian customers perceived Mobile banking channel as efficient and an entertaining way to produce financial services which, in turn, facilitated the impacting role of price value in predicting the customers' intention. Moreover, a large number of respondents are on a medium-sized income and consequently are more sensitive to price issues (Brown and Venkatesh, 2005; Dwivedi and Lal, 2007; Jaruwachirathanakul and Fink, 2005; Riffai et al., 2012; Sathye, 1999). In agreement with this assumption, Cruz et al. (2010) argued that the monetary cost was found to be the most important barrier mitigating the intention to adopt Mobile banking among the younger customers who have a lower income and enjoy a higher education level. The important influence of perceived value or price value has been empirically supported over prior literature of online banking channels (Ho and Ko, 2008).

\subsection{Theoretical Contributions}

Having studied the most important factors predicting Jordanian customers' intention and adoption of Mobile banking, the current study represents a substantial contribution to existing knowledge regarding online banking channels and technology acceptance area in general. In fact, this study represents a worthwhile direction by examining Mobile banking which, so far, has not been well evaluated in the Jordanian context. Thus, this study significantly contributes to the knowledge and literature in Jordan by focusing more on Mobile banking as more novel technology in Jordan and is calling for further understanding; examining other important aspects; and applying advanced statistical analyses method (e.g. SEM).

As the UTAUT2 is precisely theorised to explain technology acceptance from the customers' perspective (Venkatesh et al., 2012), it has been selected as a fitting theoretical foundation for the conceptual model. Therefore, this study comprises a substantial contribution by being the 
initiator in building the conceptual model based on a theoretical foundation appropriate with the customers' context and being able to capture the most important aspects forming customer intention and behaviour toward Mobile banking as well. It is also worth indicating that Venkatesh et al. (2012) empirically examined the validity of UTAUT2 to explain the acceptance of mobile Internet services in Hong Kong, a highly developed country. Thus, this study is one of the forefront studies extending the applicability of UTAUT2 by examining new technologies (Mobile banking) in a new context (banking industry) in developing countries (Jordan).

This study also goes beyond what Venkatesh et al. (2012) proposed in UTAUT2 by including a new construct (trust) alongside the UTAUT2 constructs; and proposing new causal paths between the main antecedences of behavioural intention $(\mathrm{EE} \rightarrow \mathrm{PE}$ and $\mathrm{TR} \rightarrow \mathrm{PE})$. This, in turn, demonstrates a significant contribution to the expansion of the theoretical horizon of UTAUT2. Further, using Mobile banking as a novel and innovative technology could accelerate the customers' feeling of pleasure, fun, and enjoyment; however, hedonic motivation has derived less attention from prior studies that have examined Mobile banking.

\subsection{Implications to Practice}

From practical perspective, the statistical results support the crucial role of the following factors: behavioral intention, performance expectancy, effort expectancy, facilitating conditions, price value, hedonic motivation, and trust. Hence, aspects relating to these factors must be the focus of attention of any bank in their endeavour to motivate their customers to use Mobile banking. According to Laukkanen et al. (2009), personal communication (one-toone marketing actions) is one of the best ways to persuade potential users that using the online banking channels is be more useful and advantageous compared with traditional encounters. Besides, allowing customers to try using these applications through experimental accounts rather than using their own accounts could create a positive experience and let customers actually experience how much they will benefit by using these valuable, useful and easier applications (Dwivedi and Irani, 2009; Ho and Ko, 2008; Jaruwachirathanakul and Fink, 2005).

The results of this study also provided clues for Jordanian banks about the important influence of trust. Therefore, banks have to initially be sure that Mobile banking channels are able to conduct financial transactions efficiently, securely, and within less time along with the availability of information required by customers to successfully use these channels (Chiu et al., 2010; Jaruwachirathanakul and Fink, 2005; Simintiras et al., 2014). Practically, expanding 
the range of financial services provided by the SSTs and maintaining the permanency of their performance efficiently and effectively $24 / 7$ will positively reflect on the customers' perception toward Mobile banking as more useful and trustworthy channel to produce the banking services support the role performance expectancy (Simintiras et al., 2014; Zhou, 2012; Zhou et al., 2010).

Noteworthy, Jordanian banks could also utilise breakthroughs in the social media to conduct their campaigns in a more influential and cost-effective way. In this respect, attractive videos posted on YouTube, Facebook, Twitter could explain how these channels are contemporary and breaking new ground; this could contribute to hedonic values related to such system (Chen et al., 2014). Customizing a smart, high quality and creative interface design based on the customers' preferences will lead to adding value in the terms of innovativeness and uniqueness (Dwivedi et al., 2013; Simintiras et al., 2014). This may accelerate further hedonic motivation in using SSTs (Dwivedi and Irani, 2009).

This study also indicated that Jordanian customers' intention seems to be derived by the role of price value. Banks could enhance the price value by convincing their customers that implementing this technology will provide them with a better quality of life and will save them time, cost, and effort which makes using SSTs more valuable relative to the cost paid in this regard. In addition, special price discounts or using these services for free could be another effective tactic in contributing to price value; this could increase customers' intention (How and Koi, 2008; Venkatesh et al., 2012; Wessels and Drennan, 2010) as well as motivating potential adopters to be actual adopters of Mobile banking (Laukkanen et al., 2009).

\section{Limitations and Future Research Directions}

Even though this study represents a fruitful attempt over the area of adoption and use of Mobile banking, it is restricted by the number of limitations. For instance, the data of the current study was obtained by using a convenience sample of Jordanian banking customers in only two Jordanian cities (Amman and Al-Balqa), which in turn, could negatively reflect on the generalisability of results across other cities. The sample description also showed that the largest segment of the respondents in the current study were young, have a medium-sized income, well-educated, and have adequate experience with the computer and Internet. Therefore, this raises concerns regarding the applicability of the results for other segments of the current population that have different characteristics (e.g. age, income, education level, gender, and technology experience). This study only covered one online banking channel (i.e. 
Mobile banking). This could mitigate the applicability of the current study's results to other types of electronic channels across other contexts. Further, the results of the current study were based on cross-sectional data, and therefore, raising question about the applicability of these results in the long term. Indeed, this concern could be attributed to the fact that the customers' predisposition, beliefs, and awareness toward such technologies are more likely to change in the passage of time (Agarwal and Karahanna, 2000; Lee et al., 2003). By the same token, the impacting role of the national culture on the Jordanian customers' intention and use of Mobile banking was not measured in the current study. In essence, examining the aspects related to the prevailing culture (e.g. masculinity, femininity, collectivism, individualism, uncertainty avoidance, and power distance) could be more useful to know more on how customers formulate their intention, behaviour, and beliefs towards such innovative systems (Al-Sukkar and Hasan, 2005; Constantiou et al., 2009).

Given that the results of the current study are based on cross-sectional data, a longitudinal study could provide further understanding regarding this problem and the extent of how much the effect of the proposed factors could be stabilised or changed over time. Moreover, as this study collected the required data from only two cities in Jordan (Amman and Al-Balqa'), future studies in Jordan should expand to the whole of the geographical coverage by including other cities and covering both urban and rural areas. Having a systematic process in proposing and validating the conceptual model of the current study, opening prospects to reapply and retest this model to explain customers' intention and behaviour towards different technologies (e.g. e-learning, online shopping, mobile payment, mobile government, airline self-service check-in, kiosk) in different contexts (government, health informatics, education, hotels) would be beneficial. Owing to the fact that an SST (e.g. Mobile banking) is the new technology in Jordan and its adoption rate is still sluggish, Jordanian customers have not yet formulated a habitual behaviour toward this technology; habit was excluded from the conceptual model of this study. However, in the long term, once the Jordanian customers get used to dealing with online banking channels and formulating habitual behaviour towards this technology, it becomes possible for future studies to address the role of habit on both intention and actual behaviour.

\section{Conclusion}

Mobile banking technology represents an attractive area of interest to be examined and studied especially considering the main challenges accompanied by introducing such technology. Taking in to account the lower adoption rate of Mobile banking by Jordanian 
customers, this study realised the necessity of examining the main factors that could shape the Jordanian customers' intention and adoption of Mobile banking. This is in addition to the fact that there are a quite few studies that have addressed the related issues of Mobile banking in Jordan. Furthermore, there was a need to select the theoretical foundation which is able to capture the most important aspects associated the adoption of Mobile banking by Jordanian banking customer. Thus, a new model of Venkatesh et al. (2012) UTUAT2 was selected to propose the conceptual model of the current study. This was extended by including trust as external factor have been extensively citied as one of the most important predictor of the customers intention and adoption of online banking channels. The main statistical results supported the predictive validity of the conceptual model by accounting about $64 \%$ of variance in the Jordanian customers' intention to adopt Mobile banking. Performance expectancy, effort expectancy, hedonic motivation, price value and trust all were approved to be significant predictors of the behavioural intention. Both behavioural intention and facilitating conditions were also supported to be significant factor predicting the actual adoption of Mobile banking.

\section{References}

Ajzen, I. (1991). The theory of planned behaviour. Organizational Behaviour and Human Decision Processes, 50(2), 179-211.

Alalwan, A., Dwivedi, Y. K. and Williams, M. D. (2014). Examining factors affecting customer intention and adoption of Internet banking in Jordan. In Proceedings of United Kingdom Academy of Information Systems UKAIS Conference, $7^{\text {th }}-9^{\text {th }}$ April 2014, Oxford, UK.

Alalwan, A. A., Dwivedi, Y. K., and Williams, M. D. (2016b). Customers' Intention and Adoption of Telebanking in Jordan. Information Systems Management, 33(2), 154178.

Alalwan, A. A., Rana, N. P., Dwivedi, Y. K., Lal, B., \& Williams, M. D. (2015a). Adoption of Mobile Banking in Jordan: Exploring Demographic Differences on Customers' Perceptions. In Open and Big Data Management and Innovation (pp. 13-23). Springer International Publishing.

Alalwan, A. A., Dwivedi, Y. K., Rana, N. P., Lal, B., and Williams, M. D. (2015b). Consumer adoption of Internet banking in Jordan: examining the role of hedonic motivation, habit, self-efficacy and trust. Journal of Financial Services Marketing, 20(2), 145-157.

Alalwan, A. A., Dwivedi, Y., Rana, N. P., and Williams, M. D. (2016a). Consumer adoption of mobile banking in Jordan: examining the role of usefulness, ease of use, perceived risk and self-efficacy. Journal of Enterprise Information Management, 29(1). 
Alalwan, A. A., Dwivedi, Y. K., Rana, N. P., \& Simintiras, A. C. (2016c). Jordanian consumers' adoption of telebanking: Influence of perceived usefulness, trust and selfefficacy. International Journal of Bank Marketing, 34(5).

Anderson, J. C. and Gerbing, D. W. (1988). Structural equation modelling in practice: A review and recommended two-step approach. Psychological Bulletin, 103(3), 411-423.

Awwad, M. S. and Ghadi, M. Y. (2010). Investigating of factors influencing the intention to adopt mobile banking services in Jordan. Dirasat: Administrative Sciences, 37(2), 545-556.

Bagozzi, R. P. and Yi, Y. (1988). On the evaluation of structural equation models. Journal of the Academy of Marketing Science, 16(1), 74-94.

Bank of Jordan. (2014). Bank of Jordan Mobile banking. Available from: https://itunes. apple.com/us/app/bank-of-jordan-mobilebanking/id852392335?mt=8.Accessed: 15.04.14.

Bhattacherjee, A. (2012). Social science research: Principles, methods, and practices. $\left(2^{\text {nd }}\right.$ Ed.). Florida, USA: AnolBhattacherjee.

Brislin, R. (1976). Comparative research methodology: Cross-cultural studies. International Journal of Psychology, 11(3), 215-229.

Brown, I., Cajee, Z., Davies, D., and Stroebel, S. (2003). Cell phone banking: predictors of adoption in South Africa - An exploratory study. International Journal of Information Management, 23, 381-394.

Brown, S. A. and Venkatesh, V. (2005). Model of adoption of technology in the household: A baseline model test and extension incorporating household life cycle. MIS Quarterly, 29(4), 399-426.

BuddeComm (2014). Jordan - Telecoms, Mobile, Broadband and Forecasts. Available from http://www.budde.com.au/Research/Jordan-Telecoms-Mobile-Broadband-andForecasts.html?r=51. Accessed: 08.02.15.

Byrne, B. (2010). Structural equation modeling with AMOS: Basic concepts, applications and programming. ( $6^{\text {th }}$ Ed.). New York, USA: Taylor \& Francis Group.

Chen, H., Papazafeiropoulou, A. Chen, T. K. Duan, Y., and Liu, H. W. (2014). Exploring the commercial value of social networks: Enhancing consumers' brand experience through Facebook pages. Journal of Enterprise Information Management, 27(5), 576598.

Chiu, Y., Fang, S., and Tseng, C. (2010). Early versus potential adopters: Exploring the antecedents of use intention in the context of retail service innovations. International Journal of Retail and Distribution Management, 38(6), 443-459.

Compete Pulse. (2013). Mobile Banking Today: Highlights from \#MCS2013. Available from: https://blog.compete.com/2013/06/12/mobile-banking-today-highlights-frommcs2013/. Accessed: 15.2.2015. 
Cruz, P., Neto, L. B. F., Munoz-Gallego, P., and Laukkanen, T. (2010). Mobile banking rollout in emerging markets: Evidence from Brazil. International Journal of Bank Marketing, 28(5), 342-371.

Davis, F. D. Bagozzi, R. P. and Warshaw, P. R. (1989). User acceptance of computer technology: A comparison of two theoretical models. Management Science, 35(8), 982-1003.

Dodds, W. B., Monroe, K. B., and Grewal, D. (1991). Effects of price, brand, and store information on buyers. Journal of Marketing Research, 28(3), 307-319.

Dwivedi, Y. K. and Irani, Z. (2009). Understanding the adopters and non-adopters of broadband. Communications of the ACM, 52(1), 122-125.

Dwivedi, Y. K. and Lal, B. (2007). Socio-economic determinants of broadband adoption. Industrial Management \& Data Systems, 107(5), 654-671.

Dwivedi, Y. K., Kapoor, K. K., Williams, M. D., and Williams, J. (2013). RFID systems in libraries: An empirical examination of factors affecting system use and user satisfaction. International Journal of Information Management, 33(2), 367-377.

Eriksson, K., Kerem, K., and Nilsson, D. (2005). Customer acceptance of Internet banking in Estonia. International Journal of Bank Marketing, 23(2), 200-216.

Gefen, D., Karahanna, E., and Straub, D. W. (2003). Trust and TAM in online shopping: An integrated model. MIS Quarterly, 27(1), 51-90.

Gerrard, P. and Cunningham, J. B. (2003). Diffusion of Internet banking among Singapore consumers. International of Bank Marketing, 21(1), 16-29.

Gerrard, P., Cunningham, J. B., and Devlin, J. F. (2006). Why consumers are not using Internet banking: A qualitative study. Journal of Services Marketing, 20(3), 160-168.

Gu, J. C., Lee, S. C., and Suh, Y. H. (2009). Determinants of behavioral intention to mobile banking. Expert Systems with Applications, 36(9), 11605-11616.

Hair Jr., J. F., Anderson, R. E., Tatham, R. L., and Black, W. C. (1995). Multivariate data analysis with readings. Englewood Cliffs, NJ: Prentice-Hall.

Hair Jr., J. F., Black, W. C., Babin, B. J., and Anderson, R. E. (2010). Multivariate data analysis: A global perspective. ( $7^{\text {th }}$ Ed.). Pearson Education International.

Hair Jr., J. F., Black, W., Babin, B., Anderson, R. E., and Tatham, R. (2006). Multivariate data analysis. (6 ${ }^{\text {th }}$ Ed.). New Jersey: Prentice Hall.

Hanafizadeh, P., Behboudi, M., Koshksaray, A. A., and Tabar, M. J. S. (2014). Mobilebanking adoption by Iranian bank clients. Telematics and Informatics, 31(1), 62-78.

Ho, S. and Ko, Y. (2008). Effect of self-service technology on customer value and customer readiness: The case study of Internet banking. Internet Research, 18(4), 427-446.

Holmes-Smith, P., Coote, L., and Cunningham, E. (2006). Structural equation modelling: From the fundamentals to advanced topics. Melbourne: School Research, Evaluation and Measurement Services. 
Hossain, M. A., and Dwivedi, Y. K. (2014). What improves citizens' privacy perceptions toward RFID technology? A cross-country investigation using mixed method approach. International Journal of Information Management, 34(6), 711-719.

Jaruwachirathanakul, B. and Fink, D. (2005). Internet banking adoption strategies for a developing country: The case of Thailand. Internet Research, 15(3), 295-311.

Jeong, B. K. and Yoon, T. E. (2013). An empirical investigation on consumer acceptance of mobile banking services. Business \& Management Research, 2(1), 31-40.

Khraim, H. S., Shoubaki, Y. E., and Khraim, A. S. (2011). Factors affecting Jordanian consumers' adoption of mobile banking services. International Journal of Business and Social Science, 2(20), 96-105.

Kim, G., Shin, B. and Lee, H. G. (2009). Understanding dynamics between initial trust and usage intentions of mobile banking. Information Systems Journal, 19(3), 283-311.

Kline, R. B. (2005). Principles and practice of structural equation modelling. New York: The Guilford Press.

Kline, R. B. (2011). Principles and practice of structural equation modelling. New York: The Guilford Press.

KPMG International. (2009). Consumers taking charge, consumers and convergence III survey report. Available at: www.kpmg.com//en/IssuesAndInsights/Articles Publications/Documents/Consumers-and-Convergence-III.pdf. Accessed: 10.04.12.

Laukkanen, T. and Cruz, P. (2009). Comparing consumer resistance to Mobile banking in Finland and Portugal. E-Business and Telecommunications. 48, 89-98.

Laukkanen, T. and Pasanen, M. (2008). Mobile banking innovators and early adopters: How they differ from other online users?. Journal of Financial Services Marketing, 13(2), 86-94.

Laukkanen, T., Sinkkonen, S., and Laukkanen, P. (2009). Communication strategies to overcome functional and psychological resistance to Internet banking. International Journal of Information Management, 29(2), 111-118.

Laukkanen, T., Sinkkonen, S., Kivijärvi, M., and Laukkanen, P. (2007). Innovation resistance among mature consumers. The Journal of Consumer Marketing, 24(7), 419-427.

Lee, E., Kwon, K., and Schumann, D. (2005). Segmenting the non-adopter category in the diffusion of Internet banking. International Journal of Bank Marketing, 23(5), 414437.

Lee, H., Harindranath, G., Oh, S., and Kim, D. J. (2014). Provision of Mobile banking services from an actor-network perspective: Implications for convergence and standardization. Technological Forecasting and Social Change. Doi:10.1016/j.techfore.2014.02.007.

Lee, M. C. (2009). Factors influencing the adoption of Internet banking: An integration of TAM and TPB with perceived risk and perceived benefit. Electronic Commerce Research and Applications, 8(3), 130-141. 
Lee, M., McGoldrick, P. J., Keeling, K. A., and Doherty, J. (2003). Using ZMET to explore barriers to the adoption of $3 \mathrm{G}$ mobile banking services. International Journal of Retail and Distribution Management, 31(6), 340-348.

Lin, H. F. (2011). An empirical investigation of mobile banking adoption: The effect of innovation attributes and knowledge-based trust. International Journal of Information Management, 31(3), 252-260.

Lin, H. F. (2013). Determining the relative importance of mobile banking quality factors. Computer Standards \& Interfaces, 35(2), 195-204.

Luarn, P. and Lin, H. H. (2005). Toward an understanding of the behavioral intention to use Mobile banking. Computers in Human Behavior, 21(6), 873-891.

Luo, X., Li, H., Zhang, J., and Shim, J. P. (2010). Examining multi-dimensional trust and multifaceted risk in initial acceptance of emerging technologies: An empirical study of Mobile banking services. Decision Support Systems, 49(2), 222-234.

Martins, G., Oliveira, T., and Popovic, A. (2014) Understanding the Internet banking adoption: A unified theory of acceptance and use of technology and perceived risk application. International Journal of Information Management, 34(1), 1-13.

Migdadi, Y. K. A. (2012). The developing economies' banks branches operational strategy in the era of e-banking: The case of Jordan. Journal of Emerging Technologies in Web Intelligence, 4(2), 189-197.

Nunnally, J. C. (1978). Psychometric theory. New York, NY: McGraw-Hill.

Purwanegara, M., Apriningsih, A., and Andika, F. (2014). Snapshot on Indonesia regulations in Mobile Internet banking users' attitudes. Procedia-Social and Behavioral Sciences, 115, 147-155.

Püschel, J., Mazzon, J. A., and Hernandez, J. M. C. (2010). Mobile banking: Proposition of an integrated adoption intention framework. International Journal of Bank Marketing, 28(5), 389-409.

Riffai, M. M. M. A., Grant, K., and Edgar, D. (2012). Big TAM in Oman: Exploring the promise of on-line banking, its adoption by customers and the challenges of banking in Oman. International Journal of Information Management, 32(3), 239-250.

Riquelme, H. E. and Rios, R. E. (2010). The moderating effect of gender in the adoption of Mobile banking. International Journal of Bank Marketing, 28(5), 328-341.

Rogers, E. M. (2003). Diffusion of innovations ( $5^{\text {th }}$ Ed.). New York, NY: Free Press.

Sathye, M. (1999). Adoption of Internet banking by Australian consumers: an empirical investigation. International Journal of Bank Marketing, 17(7), 324-334.

Simintiras, A. C., Dwivedi, Y. K., and Rana, N. P. (2014). Can marketing strategies enhance the adoption of electronic government initiatives? International Journal of Electronic Government Research (IJEGR), 10(2), 1-7.

Straub, D., Boudreau, M. C., and Gefen, D. (2004). Validation guidelines for IS positivist research. The Communications of the Association for Information Systems, 13(1), 63. 
The Gulf Today. (2012). Jordan's Internet users stand at 3.535 million: August 19, 2012. Available from: http://gulftoday.ae/portal/cf77a112-4874-4abe-bba8-4265dc1aa8c9. aspx. Accessed: 08.01.14.

The Jordan Times. (2013). Mobile phone penetration projected to reach 200\%. Available from: http://jordantimes.com/mobile-phone-penetration-projected-to-reach-200, Accessed: 25.12.13.

van der Heijden, H. (2004). User acceptance of hedonic information systems. MIS Quarterly, 28(4), 695-704.

Venkatesh, V., Morris, M., Davis, G., and Davis, F. (2003). User acceptance of information technology: Toward a unified view. MIS Quarterly, 27(3), 425-478.

Venkatesh, V., Thong, J. Y. L., and Xu, X. (2012). Consumer acceptance and use of information technology: Extending the unified theory of acceptance and use of technology. MIS Quarterly, 36(1), 157-178.

Weerakkody, V., El-Haddadeh, R., Al-Sobhi, F., Shareef, M. A., and Dwivedi, Y. K. (2013). Examining the influence of intermediaries in facilitating e-government adoption: An empirical investigation. International Journal of Information Management, 33(5), 716-725.

Wessels, L. and Drennan, J. (2010). An investigation of consumer acceptance of M-banking. International Journal of Bank Marketing, 28(7), 547-568.

Yang, A, S. (2009). Exploring adoption difficulties in mobile banking services. Canadian Journal of Administrative Sciences, 26(2), 136-149.

Yu, C. S. (2012). Factors affecting individuals to adopt Mobile banking: Empirical evidence from the UTAUT model. Journal of Electronic Commerce Research, 13(2), 104-121.

Zhou, T. (2011). An empirical examination of initial trust in Mobile banking. Internet Research, 21(5), 527-540.

Zhou, T. (2012). Understanding users' initial trust in Mobile banking: An elaboration likelihood perspective. Computers in Human Behavior, 28(4), 1518-1525.

Zhou, T., Lu, Y., and Wang, B. (2010). Integrating TTF and UTAUT to explain Mobile banking user adoption. Computers in Human Behavior, 26(4), 760-767. 


\section{Appendix}

Table 1: Measurement Items

\begin{tabular}{|c|c|c|c|}
\hline Constructs & & Items & Sources \\
\hline \multirow{4}{*}{$\begin{array}{l}\text { Performance } \\
\text { Expectancy }\end{array}$} & PE1 & I find Mobile banking useful in my daily life. & Venkatesh et al. (2012) \\
\hline & PE2 & $\begin{array}{l}\text { Using Mobile banking increases my chances of achieving tasks that } \\
\text { are important to me. }\end{array}$ & Venkatesh et al. (2012) \\
\hline & PE3 & Using Mobile banking helps me accomplish tasks more quickly. & Venkatesh et al. (2012) \\
\hline & PE4 & Using Mobile banking increases my productivity. & Venkatesh et al. (2012) \\
\hline \multirow{4}{*}{$\begin{array}{l}\text { Effort } \\
\text { Expectancy }\end{array}$} & EE1 & Learning how to use Mobile banking is easy for me. & Venkatesh et al. (2012) \\
\hline & EE2 & My interaction with Mobile banking is clear and understandable. & Venkatesh et al. (2012) \\
\hline & EE3 & I find Mobile banking easy to use. & Venkatesh et al. (2012) \\
\hline & EE4 & It is easy for me to become skilful at using Mobile banking. & Venkatesh et al. (2012) \\
\hline \multirow{3}{*}{$\begin{array}{l}\text { Social } \\
\text { influence }\end{array}$} & SI1 & $\begin{array}{l}\text { People who are important to me think that I should use Mobile } \\
\text { banking. }\end{array}$ & Venkatesh et al. (2012) \\
\hline & SI2 & $\begin{array}{l}\text { People who influence my behaviour think that I should use Mobile } \\
\text { banking. }\end{array}$ & Venkatesh et al. (2012) \\
\hline & SI3 & People whose opinions that I value prefer that I use Mobile banking. & Venkatesh et al. (2012) \\
\hline \multirow{4}{*}{$\begin{array}{l}\text { Facilitating } \\
\text { Conditions }\end{array}$} & FC1 & I have the resources necessary to use Mobile banking. & Venkatesh et al. (2012) \\
\hline & FC2 & I have the knowledge necessary to use Mobile banking. & Venkatesh et al. (2012) \\
\hline & FC3 & Mobile banking is compatible with other technologies I use. & Venkatesh et al. (2012) \\
\hline & FC4 & $\begin{array}{l}\text { I can get help from others when I have difficulties using Mobile } \\
\text { banking. }\end{array}$ & Venkatesh et al. (2012) \\
\hline \multirow{3}{*}{$\begin{array}{l}\text { Hedonic } \\
\text { Motivation }\end{array}$} & HM1 & Using Mobile banking is fun. & Venkatesh et al. (2012) \\
\hline & HM2 & Using Mobile banking is enjoyable. & Venkatesh et al. (2012) \\
\hline & HM3 & Using Mobile banking is entertaining. & Venkatesh et al. (2012) \\
\hline \multirow{4}{*}{ Price Value } & PV1 & Mobile banking is reasonably priced. & Venkatesh et al. (2012) \\
\hline & PV2 & Mobile banking is good value for the money. & Venkatesh et al. (2012) \\
\hline & PV3 & At the current price, Mobile banking provides good value. & Venkatesh et al. (2012) \\
\hline & BI1 & I intend to use Mobile banking in the future. & Venkatesh et al. (2012) \\
\hline
\end{tabular}




\begin{tabular}{|l|l|l|l|}
\hline \multirow{3}{*}{$\begin{array}{l}\text { Behavioural } \\
\text { Intention }\end{array}$} & BI2 & I will always try to use Mobile banking in my daily life. & Venkatesh et al. (2012) \\
\cline { 2 - 4 } & BI3 & I plan to use Mobile banking in future. & Venkatesh et al. (2012) \\
\cline { 2 - 4 } & BI4 & I predict I would use Mobile banking in the future. & Venkatesh et al. (2003) \\
\hline \multirow{5}{*}{ Trust } & TR1 & I believe that Mobile banking is trustworthy. & Gefen et al. (2003) \\
\cline { 2 - 4 } & TR2 & I trust in Mobile banking. & Gefen et al. (2003) \\
\cline { 2 - 4 } & TR3 & I do not doubt the honesty of Mobile banking. & Gefen et al. (2003) \\
\cline { 2 - 4 } & TR4 & $\begin{array}{l}\text { I feel assured that legal and technological structures adequately protect } \\
\text { me from problems on Mobile banking. }\end{array}$ & Gefen et al. (2003) \\
\cline { 2 - 4 } & TR5 & $\begin{array}{l}\text { Even if not monitored, I would trust Mobile banking to do the job } \\
\text { right. }\end{array}$ & Gefen et al. (2003) \\
\cline { 2 - 4 } & TR6 & Mobile banking has the ability to fulfil its task. & Gefen et al. (2003) \\
\hline \multirow{5}{*}{ Adoption } & Service 1 & Balance enquiries and downloaded bank statements & Püschel et al. (2010), Zhou et al. (2010), Zhou et al. (2010) \\
\cline { 2 - 4 } & Service 2 & Funds transfer & Püschel et al. (2010), Zhou et al. (2010) \\
\cline { 2 - 4 } & Service 3 & Requesting cheque book or bank certificates & Püschel et al. (2010), Zhou et al. (2010) \\
\cline { 2 - 4 } & Service 4 & Paying bills & \\
\cline { 2 - 4 } & Service 5 & Request increase in credit card(s) limit or pay any balance due & (2010), Zhou et al. (2010) \\
\hline
\end{tabular}

